\title{
The Role of United Territorial Communities in the Development Foreign Economic Activity of Agricultural Producers
}

\author{
HANNA S. FEDOSIEIEVA $^{i}$
}

The paper describes the mechanism of cooperation between the united territorial communities and agricultural producers. An example of the activities of a particular rural territorial community identifies the benefits of such cooperation for each participant. In particular, the most important positive results for the united territorial communities are: development of employment of the local population; development of social and rehabilitation of industrial infrastructure; an increase in the average wage; reducing the rate of migration of young people. The system of measures to be taken by the united territorial community in order to stimulate the export operations of local agricultural producers is justified. The factors that should be taken into account by agricultural producers in the process of joint development of the strategy of entering the foreign market are identified: identification of the object and the country of export; study of legislation in the field of agricultural imports of the partner country; the possibility of involving an external specialist in foreign economic activity and international certification; search for a foreign partner; calculation of economic efficiency of the planned export operation; others. The export options are presented for certain agricultural producers, taking into account their modern specialization, the possibility of diversification of activities, the volume of agricultural lands, the export price for certain types of products, promising markets and the available competitive advantages. The focus is on the expediency of exporting niche types of agricultural products, including white beans. In addition, the emphasis is placed on the need to consolidate the provisions of mutually beneficial parity cooperation and to determine the parameters of a concrete positive effect of such cooperation for the united territorial community.

Keywords: agricultural producer, export, foreign economic activity, united territorial community.

Introduction. Today, society is beginning to realize that the state of economic development of a country depends directly on the ability and interest of communities to engage in local development in their territory. Territorial communities are transformed from a management object into a management subject and form their own viability. Local selfgovernment bodies have been given the opportunities and motivation for the proper exercise of powers. For the first time in the history of independent Ukraine, territorial communities should be responsible for planning their development and budget, for economic development, attracting investments and developing entrepreneurship.

For the development of foreign economic activity of agricultural enterprises, Ukraine, it has such natural competitive advantages as sufficient labor force, favorable climatic conditions, abundant agricultural resources, the availability of large amount of water resources, recent progress in agricultural trade and enterprise development, as well proximity to major foreign markets with ever-growing demand for agricultural products.

\footnotetext{
${ }^{\mathrm{i}}$ Hanna S. Fedosieieva, D.Sc. (Economics), Associate Professor, Associate Professor of the Department of Public Administration and Administration and International Economics, Mykolayiv National Agrarian University.

(C) H. S. Fedosieieva, 2020.

https://doi.org/10.21272/mer.2020.87.08
} 


\section{Г. С. Федосєєва. Роль об'єднаних територіальних громад}

у розвитку зовнішньоекономічної діяльності виробників сільськогосподарської продукції

The development of foreign economic activity in agriculture of Ukraine has the following basic characteristics:

- agricultural export is the main type of foreign economic activity of agricultural enterprises;

- foreign trade turnover of agricultural products has a positive balance;

- $55 \%$ of agricultural exports come to 10 countries, and the top 10 products account for $80 \%$ of total exports;

- the basis of import of agricultural enterprises are seeds, plant protection products, fertilizers, agricultural machinery;

- increasing the presence of agricultural enterprises on EU markets, establishing mutually beneficial relations with Chinese enterprises;

- increasing the volume of attracting foreign investment in agriculture; a significant number of Ukrainian agricultural producers sell their products to traders without going to the foreign market on their own;

- increase of activity of state bodies (Ministry of Ministry of Economic Development, Trade and Agriculture, State Service of Ukraine for Food Safety and Consumer Protection, State Service of Ukraine for Geodesy, Cartography and Cadastre, etc.) and non-governmental organizations (Ukrainian Club of Agriculture Business, Trade-industrial chamber of Ukraine and its regional representations, the Ukrainian Grain Association, etc.) in the direction of promoting the development of foreign economic activity of Ukrainian agricultural enterprises and others.

Thus, although the foreign economic activity of agricultural enterprises in Ukraine, in most cases is a positive phenomenon, which contributes to the development of enterprises themselves, certain regions of Ukraine and the national economy, there are a number of problematic aspects that hold it back. These problems can be overcome with the participation of state authorities, local self-government bodies, public organizations and institutions and the agricultural enterprises themselves.

Problem statement. The development of foreign economic activity of agricultural enterprises are described in the works of O. O. Holosova, L. A. Zubchenko, S. M. Kwasha, A. V. Klyuchnik, K. V. Nakonechna, V. S. Nitsenko and others. At the same time, the problem of development of foreign economic activity in the united territorial communities remains a new and relevant topic for domestic scientists and practitioners.

The purpose of the work is to define the role of the united territorial communities in the development of foreign economic activity of agricultural enterprises and to substantiate on this basis a mechanism to stimulate the development of foreign economic activity of agricultural enterprises with the participation of the united territorial communities.

The susults of reearch. United Territorial Communities (hereinafter referred to as UTC), as entities of managing the agricultural business development, can provide both real financial support and assistance through certain management tools. Among them: consultations; audit monitoring the implementation of agricultural activities; holding various roundtables and conferences with the invitation of experts of state authorities on carrying out foreign economic activity, enterprises that already have such operations and others.

However, despite the existing theoretical basis for the management of foreign economic activity of agricultural enterprises, most of the existing united territorial communities do not use them, leaving the enterprise alone with existing problems and challenges. Although, at the same time, united territorial communities want to receive additional financial resources from the operating on their territory agricultural enterprises for the development of industrial and 
Hanna S. Fedosieieva. The Role of United Territorial Communities in the Development Foreign Economic Activity of Agricultural Producers

social infrastructure, patronage assistance, support of various cultural and sports events etc. Therefore, we believe that for the purpose of a parity, mutually beneficial interaction between the studied enterprises and the united territorial communities the latter should not nominally, but actually assist agricultural enterprises in the organization and implementation of foreign trade operations.

The possibility of UTC participation in the development of foreign economic activity of agricultural producers will be considered on the example of the Nechaansky rural territorial community of Mykolaiv region, formed on December 18, 2016. This UTC includes 10 settlements: 6 villages and 4 villages.

The main employment of the local population of the Nechaansky rural territorial community is agriculture, the activity of agricultural producers brings more than half of the budget revenues. Therefore, further development of individual agricultural producers is beneficial throughout the UTC, Fig. 1.

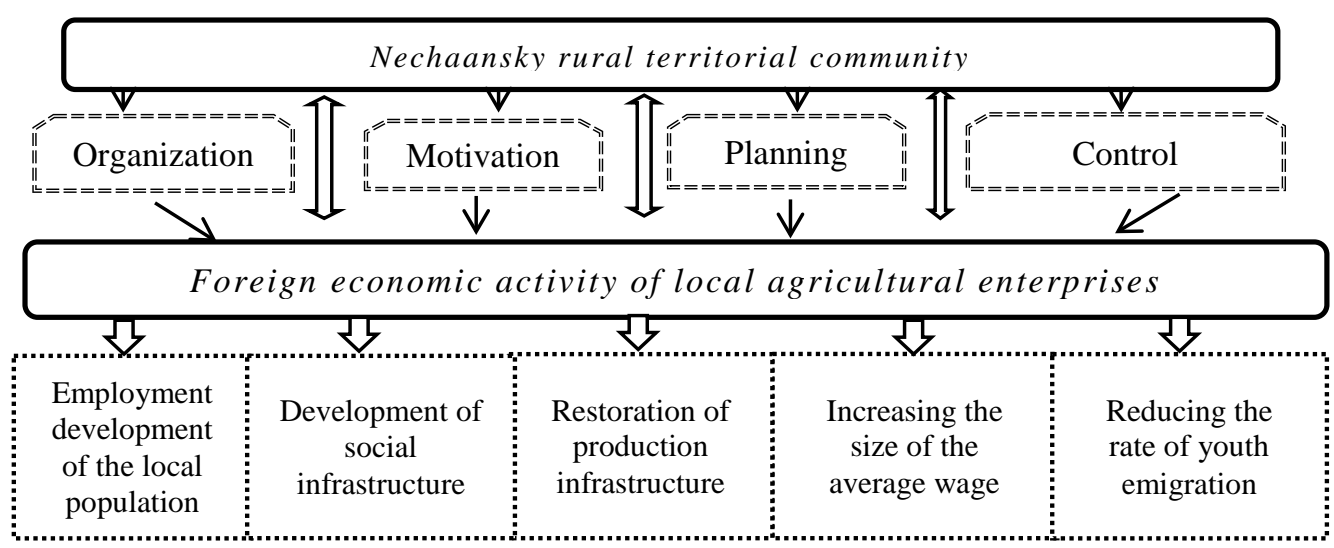

Figure 1. Interconnection of the Nechaansky rural territorial community activities and development of foreign economic activity of local agricultural enterprises

In 2018, there were 27 agricultural producers working in the Nechaansky rural territorial community. The largest of which are: LLC "Ivanivske", LLC "S-Rostock", SGVK "Urozhayniy”, FG "Vasilyok”, FG "Verbovy”, FG “Zubenko V. V”. From the above list, only LLC "Ivanivske", and LLC "S-Rostock", have experience in foreign economic activities (export of vegetables). The list of agricultural producers that could potentially become subjects of foreign economic activity is given in Table 1.

Table 1

Producers of agricultural products of the Nechayan rural territorial community of Mykolaiv region

\begin{tabular}{|l|l|r|r|r|r|}
\hline \multirow{2}{*}{ Name of enterprise } & \multirow{2}{*}{ Activity } & \multicolumn{2}{|c|}{ Area of arable land, ha } & $\begin{array}{c}\text { Growth rate of arable } \\
\text { land, 2018 by 2016, \% }\end{array}$ \\
\cline { 3 - 5 } & & 2016 p. & 2017 p. & \multicolumn{1}{c|}{$2018 \mathrm{p}}$. & 101.68 \\
\hline FG “Vasilyok” & Growing of cereals & 718 & 724 & 730 & 101.25 \\
\hline FG “Verbovy” & Growing of cereals & 523 & 529.5 & 529.5 & 102.13 \\
\hline FG “Zubenko V.V.” & Growing of cereals & 315 & 315 & 321.7 & 100.0 \\
\hline FG “Oreol” & Growing of cereals & 23.9 & 23.9 & 23.9 & 100.0 \\
\hline FG "Vita” & Growing of cereals & 29.3 & 29.3 & 29.3 & \\
\hline
\end{tabular}




\section{Г. С. Федосєєва. Роль об'сднаних територіальних громад}

у розвитку зовнішньоекономічної діяльності виробників сільськогосподарської продукції

All the above mentioned enterprises combine several factors: the location of land in the territory of one community, the main activity is the cultivation of cereals and vegetables, most of the grain production of these enterprises is sold to resellers abroad.

In our opinion, it is advisable to establish cooperation with the listed agricultural producers on the cooperation of the Nechaansky rural territorial community in their entry into the foreign market. The model of such cooperation is shown in Figure 2. It should be noted that the Nechaansky rural territorial community should assume the role of organizer of the export operation, while performing the function of motivation, organization, planning and control.

In the first stage of implementation of the presented model, it is advisable to hold an open discussion on the possibility of joint formation of a batch of products for export. The result of such negotiations is the identification of those wishing to carry out an export operation and the ability of each of the applicants to work to achieve both its overall purpose and its economic impact.

The next step is the development and implementation of measures aimed at familiarizing agricultural producers with the features of the export operation. Such measures should result in the establishment of a list of enterprises that will carry out the export operation. These enterprises should agree on the main issues: the object of export (wheat, corn, barley or possibly niche products - mustard, buckwheat, white beans, etc.), export countries (level of export costs, need for international production certification, availability of tariffs and nontariff restrictions, etc.), engaging an external expert to negotiate and conclude a foreign economic contract, or to identify a responsible person - an employee of one of the enterprises (or the unit of management of a rural territorial community); methods of searching for a foreign partner (Internet resource, involvement of Regional chamber of commerce and industry organizations) and checking its reliability, etc.

It is worth noting that the export of agricultural products by producers who are on the simplified system of taxation (are payers of a single tax) does not provide for the payment of separate taxes and fees (income tax) except those provided for the passage of the customs border of Ukraine. Thus, according to an official explanation of the State Fiscal Service: “... 39.2.1.1 Nos. 39.2.1 clause 39.2 of Article 39 of the Tax Code of Ukraine dated 02.12.2010 № 2755 - VI with amendments stipulate that controlled transactions are economic transactions of the taxpayer that may affect the taxation of the income tax enterprise. Pursuant to Article 297.1, Article 297 of the Tax Code of Ukraine, single tax payers to whom agricultural producers who pay a fourth group single tax are exempted from the obligation to charge, pay and file corporate income tax returns. Economic operations of such an agricultural producer by export sales of agricultural products do not affect, and cannot affect, the entity's corporate income tax, since such a taxpayer is exempt from the obligation to charge, pay, and file corporate income tax returns [6].

A qualitative assessment of the effectiveness of a planned export operation is required, preferably for multiple export options, with a full understanding of what competitive advantages are available to businesses for each export option, and what competitive advantages can be gained in the future. In doing so, it is important to correctly calculate the full export costs, export sales revenue, economic impact and economic efficiency of exports. Possible options for exporting agricultural producers are shown in Table 2. 
Hanna S. Fedosieieva. The Role of United Territorial Communities in the Development Foreign Economic Activity of Agricultural Producers

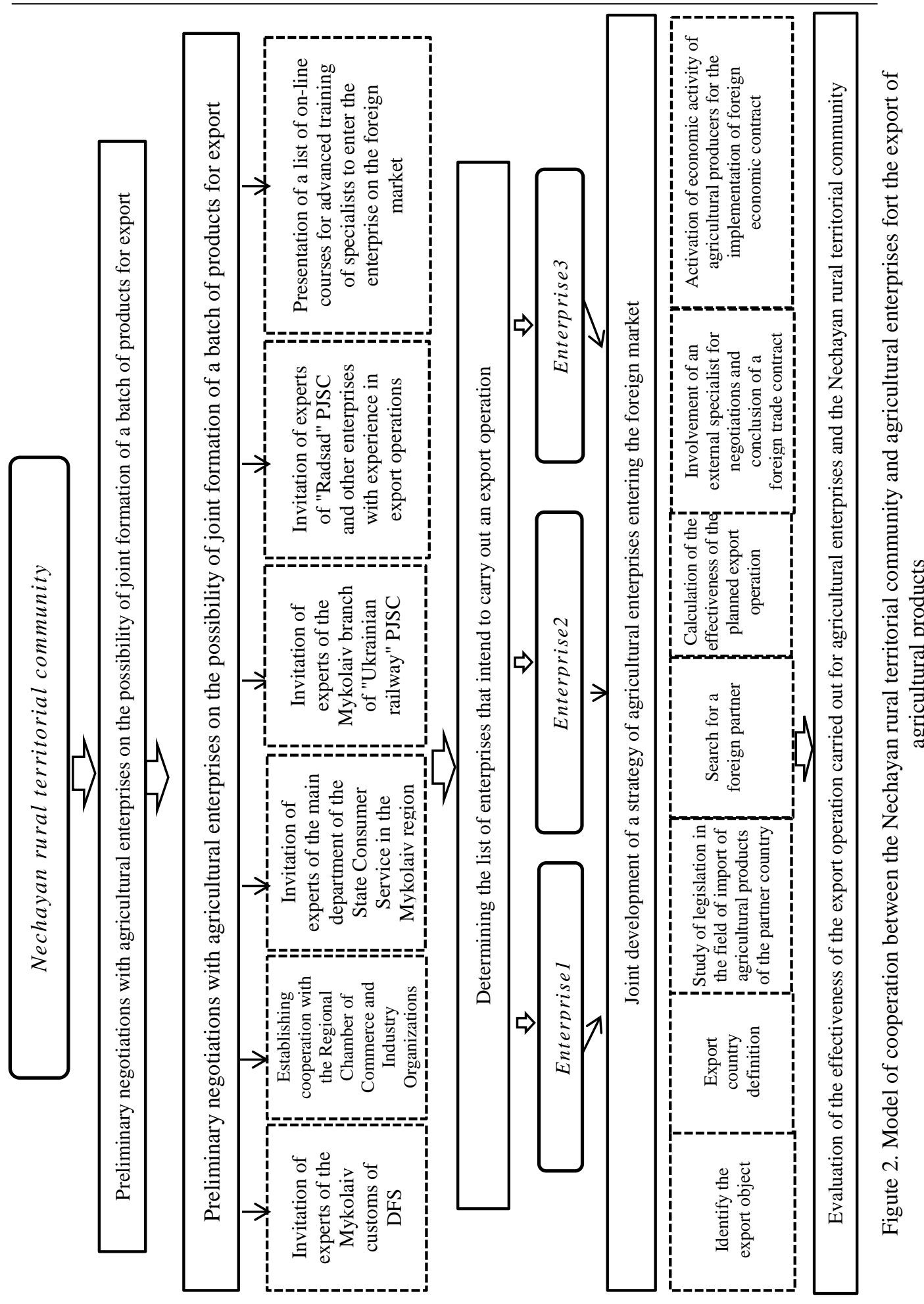


Г. С. Федосєєва. Роль об'єднаних територіальних громад

у розвитку зовнішньоекономічної діяльності виробииків сільськогосподарської продукції

Table 2

Options for export of agricultural products by producers of the Nechayan rural territorial community of Mykolaiv region

\begin{tabular}{|c|c|c|c|c|c|c|c|}
\hline $\begin{array}{l}\text { Type of } \\
\text { products }\end{array}$ & $\begin{array}{l}\text { Avera } \\
\text { ge } \\
\text { harvest } \\
\text { in } \\
2018, \\
\text { c / ha }\end{array}$ & $\begin{array}{l}\text { The } \\
\text { minimum } \\
\text { the volume } \\
\text { of the batch } \\
\text { for export, } \mathrm{t}\end{array}$ & $\begin{array}{l}\text { The minimum } \\
\text { the size of } \\
\text { agricultural } \\
\text { land for } \\
\text { forming a } \\
\text { party, ha }\end{array}$ & $\begin{array}{c}\text { Average } \\
\text { export price } \\
\text { in 2017/18 } \\
\text { MY, } \\
\text { USD / t }\end{array}$ & $\begin{array}{l}\text { Incoterms } \\
\text { Terms }\end{array}$ & $\begin{array}{c}\text { Potential } \\
\text { importing } \\
\text { countries }\end{array}$ & $\begin{array}{c}\text { There are } \\
\text { competiti } \\
\text { ve } \\
\text { advantag } \\
\text { es in } \\
\text { foreign } \\
\text { markets }\end{array}$ \\
\hline Barley & 35.1 & 1000 & 287 & 189.56 & $\begin{array}{c}\text { FCA, FOB, } \\
\text { DAP }\end{array}$ & $\begin{array}{c}\text { Spain, } \\
\text { Saudi } \\
\text { Arabia, } \\
\text { Israel }\end{array}$ & $\begin{array}{l}\text { Price, } \\
\text { quality, } \\
\text { stable } \\
\text { demand }\end{array}$ \\
\hline Maize & 74.5 & 1000 & 134 & 163.58 & $\begin{array}{c}\text { FCA, FOB, } \\
\text { DAP }\end{array}$ & $\begin{array}{l}\text { Spain, Iran, } \\
\text { China }\end{array}$ & $\begin{array}{l}\text { Price, } \\
\text { quality, } \\
\text { stable } \\
\text { demand }\end{array}$ \\
\hline Wheat & 37.0 & 1000 & 270 & 183.58 & $\begin{array}{c}\text { FCA, FOB, } \\
\text { DAP }\end{array}$ & $\begin{array}{c}\text { Israel, } \\
\text { Tunisia, } \\
\text { Egypt }\end{array}$ & $\begin{array}{l}\text { Price, } \\
\text { quality, } \\
\text { stable } \\
\text { demand }\end{array}$ \\
\hline $\begin{array}{l}\text { The beans } \\
\text { are white }\end{array}$ & 20.2 & 10 & 5.0 & 582 & $\begin{array}{c}\text { FCA, DAP, } \\
\text { DAT }\end{array}$ & $\begin{array}{c}\text { Romania, } \\
\text { Georgia, } \\
\text { Bulgaria }\end{array}$ & $\begin{array}{l}\text { Stability } \\
\text { export } \\
\text { the } \\
\text { demand, } \\
\text { quality, } \\
\text { price }\end{array}$ \\
\hline
\end{tabular}

Given that the aforementioned agricultural producers of the Nechaan Rural Community are farms, they are advised to pay attention to growing white beans for export. This culture is niche, so the export batch of goods is minimal, so transport costs will also be minimal. In addition, there is a stable export demand in the markets of Romania, Georgia and Bulgaria, as domestic producers have already proven themselves to be reliable partners supplying quality products at reasonable prices. Interestingly, production certification for compliance with international quality systems is not a prerequisite for export to these countries. In our opinion, the main competitive advantage in these markets should be the management of exporters' competence, but they depend only on their skills and desire to export.

After conducting the export operation, it is advisable to evaluate its actual effectiveness, identify the problematic aspects and develop a plan for their minimization in the future, if necessary, to justify the directions of commodity and geographical diversification of exports.

In general, it may take several years to prepare, implement, evaluate the results of an export operation (for businesses and the Nechayan rural territorial community). So, the organizational activities of the rural territorial community should start in the spring or summer, so that in the autumn agricultural enterprises will be able to carry out all the necessary agrochemical measures for sowing a certain crop. Next year, , it is necessary not only to harvest, but also to finally determine the export country, to search for a foreign partner and all related actions to organize the export operation. It is advisable to sell products in the middle or at the end of the marketing year, when the price is highest.

It is also important to determine at the initial stage of preparation for the export operation the benefits that the Necha Rural Territorial Community will receive from the successful 
Hanna S. Fedosieieva. The Role of United Territorial Communities in the Development Foreign Economic Activity of Agricultural Producers

operation of the operation. In our opinion, in order to consolidate the social and economic effect of conducting an export operation, the STG under study should also take on assistance in organizing international certification. After all, international certification of agricultural production automatically contributes to the development of social and industrial infrastructure of rural areas.

Conclusions and prospects of further research. An important factor for ensuring the economic development of the community is the creation of all the necessary conditions for the functioning of budget-forming enterprises, which are the main sources of financial resources to local budgets. In this context, stimulating the development of foreign economic activity of agricultural enterprises in the community is one of the most useful ways of managing entrepreneurial activity in a given community. Since it is foreign economic activity that generates foreign exchange earnings, it stimulates the improvement of the quality of agricultural produce. That is what can bring not only a positive effect for the community but also a social one. It is appropriate for the UTC management itself to initiate the conduct of foreign economic operations by local agricultural producers, as this will consolidate the provisions of mutually beneficial parity cooperation and determine the parameters of the specific effect of such cooperation on the community.

Areas of further research include the study of the features of independent organization of foreign trade operations by small and medium-sized agricultural producers.

\section{References}

1. Eksportni mozhlyvosti Ukrainy [Export opportunities of Ukraine.] (2019). Ahrobiznes sohodni. Retrieved from http://agro-business.com.ua/agro/ekonomichnyi-hektar/item/12900-eksportnimozhlyvosti-ukrainy.html. - Zaholovok z ekranu. (Available at 11.03.2020).

2. Nechaianska hromada. Retrieved from https://nechayanska-gromada.gov.ua/(Available at 11.03.2020).

3. Derzhavna sluzhba statystyky Ukrainy (2019). Silske hospodarstvo Ukrainy 2018: Statystychnyi zbirnyk. Retrieved from http://www.ukrstat.gov.ua/(Available at 11.03.2020).

4. Ukrainskyi klub ahrarnoho biznesu (2018). Kyiv: Ukrainian Agrarian Business Club. Retrieved from http://ucab.ua/(Available at 11.03.2020).

5. Cherven, I. I. \& Pavliuk, S. I. (2019). Reforma detsentralizatsii i rozvytok silskykh terytorii v Ukraini [Decentralization reform and rural development in Ukraine] Visnyk ahrarnoi nauky Prychornomoria. Retrieved from https://visnyk.mnau.edu.ua/statti/2019/n102v2r2019cherven.pdf (Available at 11.03.2020).

6. Derzhavna fiskalna sluzhba Ukrainy (2019). Shchodo vyznannia hospodarskykh operatsii silskohospodarskoho vyrobnyka - platnyka yedynoho podatku chetvertoi hrupy z realizatsii produktsii na eksport kontrolovanymy operatsiiamy [Concerning the Recognition of Economic Operations of an Agricultural Producer - Payer of Single Tax of the Fourth Group on Sales of Products for Export by Controlled Transactions // State Fiscal Service of Ukraine]. Retrieved from http://sfs.gov.ua/ (Available at 11.03.2020).

Manuscript received 16 October 2019

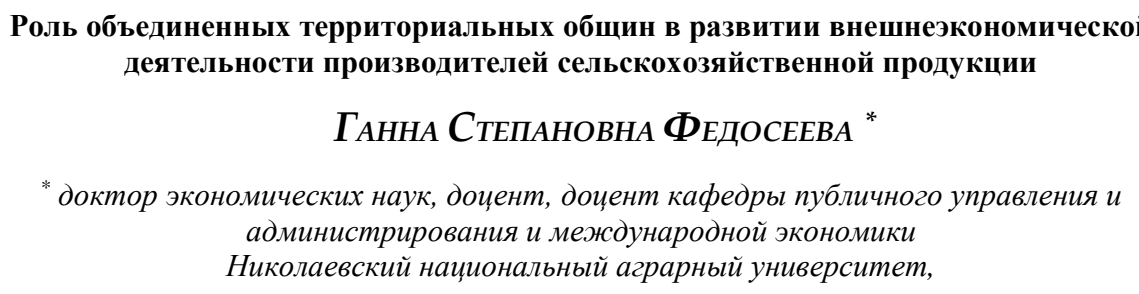


Г. С. Федосєєва. Роль об'сднаних територіальних громад

у розвитку зовнішньоекономічної діяльності виробників сільськогосподарської продукції

\author{
ул. Г. Гонгадзе, 9, г. Николаев, 54000, Украина, \\ тел.: +38(099)5048942, e-mail: timofany@ukr.net
}

В работе приведен механизм сотрудничества объединенных территориальных общин и производителей сельскохозяйственной продукции. На примере конкретной сельской территориальной общины определены преимущества от такого сотрудничества для каждого из участников. В частности, наиболее важными положительными результатами для объединенных территориальных общин названы: повышения занятости местного населения; развитие социальной и восстановление производственной инфраструктуры; увеличение размера средней заработной платы; снижение темпов миграции молодежи. Обоснована система мер, которую должна реализовать объединенная территориальная община для стимулирования экспортных операций местных производителей сельскохозяйственной продукции. Определены факторы, которые нужно учитывать сельскохозяйственным товаропроизводителям в процессе совместной разработки стратегии выхода на внешний рынок: определение объекта и страны экспорта; исследования законодательства в сфере импорта сельскохозяйственной продукции страныпартнера; возможность привлечения внешнего специалиста по внешнеэкономической деятельности и международной сертификации; поиск иностранного партнера; расчет экономической эффективности запланированной экспортной операции; другие. Представлены варианты экспорта для определенных сельскохозяйственных товаропроизводителей с учетом их современной специализации, возможности диверсификации деятельности, объема сельскохозяйственных угодий, экспортной цены на определенные виды продукции, перспективных рынков сбыта и имеющиеся конкурентные преимущества. Сосредоточено внимание на целесообразности экспорта нишевых видов сельскохозяйственной продукции, в частности фасоли белой. Кроме того, сделан акцент на необходимости закрепления положений взаимовыгодного паритетного сотрудничества и определения параметров конкретного положительного эффекта от такого сотрудничества для объединенной территориальной общины.

Ключевые слова: производитель сельскохозяйственной продукции, экспорт, внешнеэкономическая деятельность, объединенная территориальная община

$$
\begin{gathered}
\text { Mechanism of Economic Regulation, 2020, No 1, 97-105 } \\
\text { ISSN 1726-8699 (print) }
\end{gathered}
$$

\title{
Роль об'сднаних територіальних громад у розвитку зовнішньоекономічної діяльності виробників сільськогосподарської продукції
}

\section{ГАННА СТЕПАНІвНА ФЕДОсеєва *}

* доктор економічних наук, доцент,

дочент кафедри публічного управління та адміністрування і міжнародної економіки

Миколаӥвський національний аграрний університет

вул. Г. Гонгадзе, 9, м. Миколаїв, 54000, Украӥна,

тел.: +38(099)5048942, e-mail: timofany@ukr.net

У роботі наведено механізм співпраці об'єднаних територіальних громад та виробників сільськогосподарської продукції. На прикладі діяльності конкретної сільської територіальної громади визначено переваги від такої співпраці для кожного з учасників. Зокрема, найбільш важливими позитивними результатами для об'єднаних територіальних громад названо: розвиток зайнятості місцевого населення; розвиток соціальної та відновлення виробничої інфраструктури; збільшення розміру середньої заробітної плати; зниження темпів міграції молоді. Обгрунтовано систему заходів, які повинна реалізувати об'єднана територіальна громада задля стимулювання експортних операцій місцевих виробників сільськогосподарської продукції. Визначено фактори, що їх потрібно враховувати сільськогосподарським товаровиробникам в процесі сумісної 
Hanna S. Fedosieieva. The Role of United Territorial Communities in the Development Foreign Economic Activity of Agricultural Producers

розробки стратегії виходу на зовнішній ринок: визначення об'єкту та країни експорту; дослідження законодавства в сфері імпорту сільськогосподарської продукції країни-партнера; можливість залучення зовнішнього фахівця з зовнішньоекономічної діяльності та міжнародної сертифікації; пошук іноземного партнера; розрахунок економічної ефективності запланованої експортної операції; інші. Представлено варіанти експорту для визначених сільськогосподарських товаровиробників з врахуванням їх сучасної спеціалізації, можливості диверсифікації діяльності, обсягу сільськогосподарських угідь, експортної ціни на визначені види продукції, перспективні ринки збуту та наявні конкурентні переваги. Зосереджено увагу на доцільності експорту нішевих видів сільськогосподарської продукції, зокрема квасолі білої. Окрім того, зроблено акцент на необхідності закріплення положень взаємовигідної паритетної співпраці та визначення параметрів конкретного позитивного ефекту від такої співпраці для об'єднаної територіальної громади.

Ключові слова: виробник сільськогосподарської продукції, експорт, зовнішньоекономічна діяльність, об'єднана територіальна громада.

JEL Codes: P25, D13, Q17

Tables: 2; Figures: 2; References: 6

Language of the article: English

Лimepamypa

1. Експортні можливості України. Агробізнес сьогодні. [Електронний ресурс]. - Режим доступу : http://agro-business.com.ua/agro/ekonomichnyi-hektar/item/12900-eksportnimozhlyvosti-ukrainy.html. - Заголовок з екрану. (Актуально на 11.03.2020р.).

2. Нечаянська громада. [Електронний ресурс]. - Режим доступу : https://nechayanskagromada.gov.ua/ (Актуально на 11.03.2020 p.)

3. Сільське господарство України 2018 : Статистичний збірник // Державна служба статистики [Електронний ресурс]. - Режим доступу : http://www.ukrstat.gov.ua/ (Актуально на: 11.03.2020).

4. Украӥнський клуб аграрного бізнесу. [Електронний ресурс]. - Режим доступу : http://ucab.ua/ (Актуально на: 11.03.2020).

5. Червен, I. I. Реформа децентралізації і розвиток сільських територій в Україні/ I. I. Червен, С. І. Павлюк // Вісник аграрної науки Причорномор'я - 2019. - № 3 [Електронний ресурс]. Режим доступу : https://visnyk.mnau.edu.ua/statti/2019/n102v2r2019cherven.pdf (Актуально на: 11.03.2020).

6. Щодо визнання господарських операцій сільськогосподарського виробника - платника єдиного податку четвертої групи 3 реалізації продукції на експорт контрольованими операціями // Державна фіскальна служба України. [Електронний ресурс]. - Режим доступу : http://sfs.gov.ua/ (Актуально на: 11.03.2020). 